特 集 2

高分解能レーザー分光による化学反応中間体の分子構造

\title{
広田栄 治*
}

（1985年 7 月 5 日 受理）

\section{Molecular Structure of Chemical Reaction Intermediates by High-Resolution Laser Spectroscopy}

\author{
Eizi HIROTA*
}

(Received July 5, 1985)

\section{1. 高分解能レーザー分光と反応中間体}

化学は物質の変化，すなわち反応の科学であ る。価值の低い物質を材料として価値の高いも のを作り出したいという鍊金術師の精神がその 根底をなしている。昔は, 反応容器に入れる出 発物質を上手に選択する以外は，僅かに反応容 器の温度を上下したり，その中を㩭拌したりす るくらいで，化学反応を真に操作することは極 めて困難であった。しかし反応の内容を明かに する努力が積み重ねられ，従来単純な反応と思 われていたものが, いくつかのステップに分解 できることがわかってきた。このようなステッ プを素反応と呼んでいる。素反応で主役を演じ ているのは反応中間体である。これらの分子は, 完全に孤立していればもちろん安定に存在する が, 他の分子が接近すると直ちに反応して他の ものに変わってしまう。その高い反応性は通常 対を作っていない電子, 不対電子に帰着される。 化学反応を意の如く操る一つの道はこれら不対 電子をもつ反応中間体（遊離基, フリーラジカ ルという）の素性を明かにすることである。
一方，物質を診断するために人類は分光学と いう有力な手段を開発してきた。その歴史は前 世紀あるいはそれ以前にさかのぼる。しかし分 子分光学の基礎は量子力学によってはじめて与 えられたといってよいであろう。分子のもつ 3 つの代表的運動, 分子内電子の運動, 原子核 の振動, 分子全体の回転に対応して電子, 振 動, 回転スペクトルが紫外ないし可視部, 赤外 部，遠赤外ないしマイクロ波領域に観測され， その解析を通じて分子に関する情報は飛躍的に 増加した。短寿命分子についていえば，1950年 代に開発された閃光光分解法と大型可視紫外回 折格子分光器の組み合わせにより数個の原子か ら成る短寿命反応中間体の分光研究は画期的な

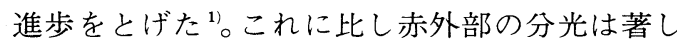
く立ち遅れた。大型回折格子分光器は第 2 次世 界大戦前に作られ戦後も活発な研究が続けられ たが, 光源が暗く, また検出器のレスポンスが 遅いことから対象は化学的に安定な分子に限ら れている。この状態は, 近年長足の進歩を遂げ たフーリェ分光法の導入によってかなり改善さ れつつあるが, 感度については依然低く多くの

* 分子科学研究所 ( T444 岡崎市明大寺町)

* The Institute for Molecular Science (Myodaiji, Okazaki 444) 
不安定分子を検出することは困難な状況である。 1960年代には回折格子を高速回転させる方式の ラピッドスキャン分光器が作られたが2), 感度, 分解能ともに低く，大きな成果をもたらすこと はなく終わった。そこで赤外域における活性短 寿命分子の分光研究は，これらを低温不活性マ トリックス中にとじ込めることによって行なわ れてきだ!。いし，これでは回転に関する情報 が一切失われ, 分子の構造を調べることが困難 になってしまう。赤外分光は, マイクロ波分光 ではほとんど研究不可能な対称性の高い無極性 の基本的分子をとりあげることができるし，電 子スペクトルにしばしば見られる前期解離など の影響を受けないなどの長所を持っている。(最 初の解離極限より上に存在する離散的準位から 分子が一定の選択律に従って無輻射遷移をおこ し連続準位に移って分解する現象をいう。多く の分子でしばしば観測される発光スペクトルは 弱くなり吸収スペクトルは幅が広がり, 極限で は両者とも消失する。）観測されるスペクトルは， 化学結合や結合角の変化と密接な関係にあり, 分子の構造について多くの有用な知見をふくん でいる。そこで画期的な光源であるレーザーを 赤外領域に持ち込み, 高感度高分解能分光法を 開発する試みが行なわれてきた。本稿はそのよ うな開発と反応中間体の分子構造研究への応用 を中心に論ずる。

\section{2. 高分解能赤外レーザー分光法}

容易に想像できるように，反応中間体を高い 濃度で生成させることはできないので, 用いる 分光法はできる限り高感度でなければならない。 また試料セルの中の大部分は, 反応物や生成物 など化学的に安定な分子であって，それらのス ペクトルによる妨害を乗り越えて目的のスペク トルを拾い出すことができるだけの高い分解能 を必要とする。

赤外レーザーのうちでもっとも早くから分子 分光学に応用されたのはいうまでもなく二酸化 炭素レーザーである。波長固定であるので, 試 料に電場をかけたり磁場をかけたりして分子の
エネルギー準位を変化させ遷移の方をレーザー 線に同調させる方法が採られた。電場掃引の場 合をレーザー・シュタルク分光, 磁場掃引の場 合をレーザー磁気共鳴 L M R と呼んでいる。反 応中間体は, 後にも述べるように, 放電によっ て生成することが多い。シュタルク分光ではし ばしば $50 \mathrm{kV} / \mathrm{cm}$ 々った高電場が必要になるの で, 反応中間体の分光には不適当である。そこ でもっぱら L M Rが用いられている。もちろん 常磁性をもつ分子種のみが対象になる。

LMRの方法は先ず遠赤外領域で開発された。 1970年頃までは, いわゆる水レーザー, 重水レ 一ザー, HCNレーザー, DCNレーザーの発振 する各々 2 〜 本のレーザー線が使えるのみで, 多くの分子を研究することはきわめて困難であ った。しかし1970年以降, 適当な分子を遠赤外 レーザー共振器中におき, 高出力 (数 $10 \mathrm{~W}$ ) の $\mathrm{CO}_{2}$ レーザーで照射すると遠赤外レーザー発振 をおこすことが知られるようになり, 現在発振 線は2000に達しようとしている ノール，ギ酸， 2 フッ化メタン， 2 フッ化エチ レン, ヒドラジンなどをレーザー媒体として用 いると連続発振でも数〜数 $10 \mathrm{~mW}$ W出力がえら れ，遠赤外 (FIR) LMRの光源としてさかんに 用いられている。著者らの用いている分光系を Fig. 1 に示す6”これを使って観測したP D カルの回転・微細構造間の遷移に対するスペク トルをFig. 2 に示す。横軸が磁場であることに 注意されたい。P Dの電子振動基底状態は ${ }^{3} \Sigma^{-}$

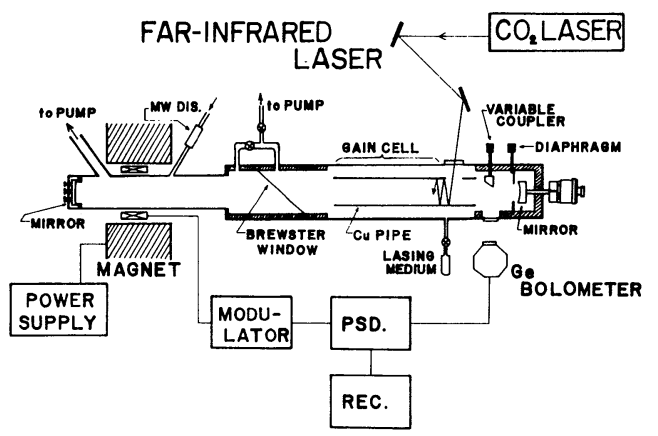

Fig. 1 Schematic diagram of a far-infrared LMR (laser magnetic resonance) spectrometer ${ }^{6}$. 


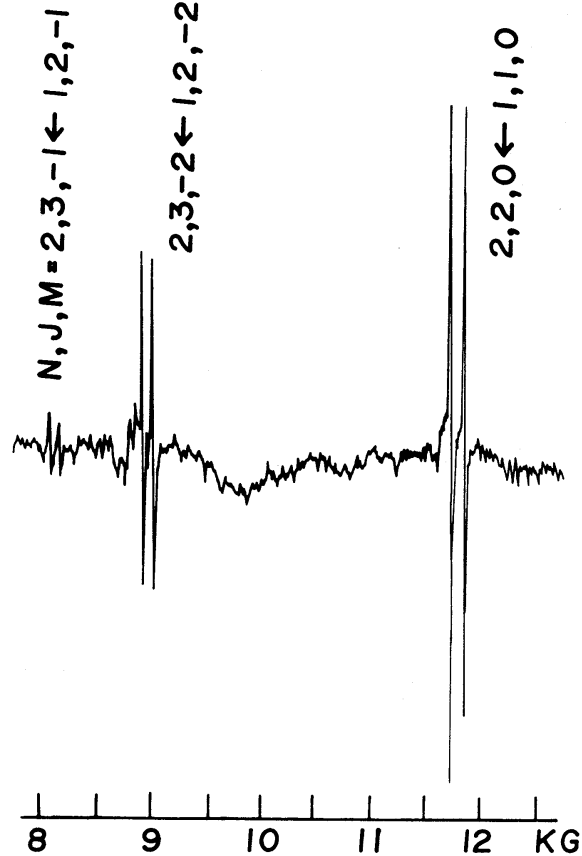

Fig. 2 Far-infrared LMR spectrum of the PD radical in the $\mathrm{X}^{2} \Sigma^{-} v=0$ state. The laser line employed is the $\mathrm{CH}_{3} \mathrm{OH} 570.6$ $\mu \mathrm{m}$ line. The $\mathrm{PD}$ radical was generated by the reaction of red phosphorus with microwave discharge products of $\mathrm{D}_{2} \mathrm{O}$. The doublet splittings are due to the ${ }^{31} \mathrm{P}$ hyperfine interaction ${ }^{6}$.

であるので，Fig. 3に示されているように量子 数 $N$ で指定されている各回転準位は 3 個のスピ ン成分 $J=N-1, N, N+1$ に分裂する（微細構 造)。Fig. 2 の 3 組の二重線はFig. 3 の右側の 3 つの遷移に対応する。各遷移が 2 本に分裂して いるのは P の核スピン $(\mathrm{I}=1 / 2)$ による超微細 相互作用のためである。

電磁石の直径は高々 $50 \mathrm{~cm}$ くいであるから, 吸収七ルの実効長もその程度におさえられる。 しかし遠赤外レーザー共振器の中に入れられて いるので, 有効長は $10^{3} \sim 10^{4}$ 倍あるものと思わ れる。実際 L M R の最大の長所は感度が非常に 高いことである。また回転スペクトルを観測す る場合, 遠赤外領域はマイクロ波, ミリ波領域 より約 1 桁程度短い波長域になるので, 吸収係

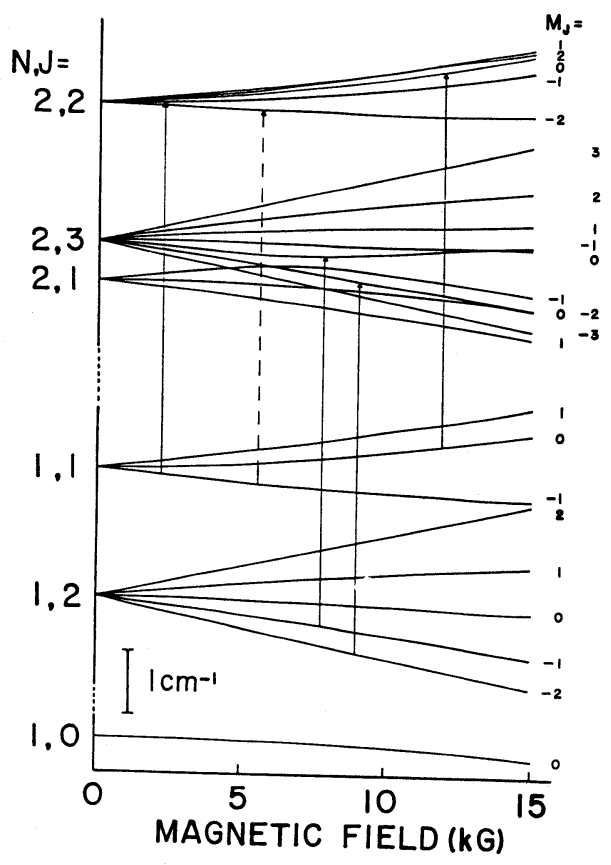

Fig. 3 Rotational energy levels with $N=1$ and 2 and their Zeeman effects calculated for the $\mathrm{PD}$ radical in the $\mathrm{X}^{3} \Sigma^{-} v=0$ state. The three vertical lines to the right correspond to three doublet lines shown in Fig. $2^{6)}$.

数が $10^{2} \sim 10^{3}$ 大きく，実効的な感度はそれだけ 高くなる。上記の例のような水素化物等軽い分 子の回転スペクトルの観測にもっとも適してい る。しかし分子がやや大きくなると, 信号の観 測は容易であるが，スペクトルの帰属は困難に なる。筆者らは7, $\mathrm{PO}_{2}$ ラジカルの回転スペクト ルを最初FIR LMRで見つけたが, 帰属はマイ クロ波分光の結果をまってはじめて完全に行な うことができた。この例の示すように，F I R L M R は不安定分子生成のための化学的諸条件 を設定するにはきわめて有用な方法である。

同じアイデアによる分光法が，赤外領域の気 体レーザー $\left(\mathrm{CO}_{2}, \mathrm{~N}_{2} \mathrm{O}, \mathrm{CO}\right)$ を光源として開 発されている。赤外 (IR) LMRである。これら のレーザーは比較的容易に製作できるので，か なり多数の分光器が作られている。この方法で は振動回転遷移が観測される。振動回転遷移の 
遷移モーメントは回転遷移より 1 桁程度小さい ので, 感度は 2 桁くらい低い。用いられている レーザーが 9 〜 $10 \mu \mathrm{m}$ あるは $5 \sim 7 \mu \mathrm{m}$ に限定 されているのも大きな短所の 1 つであるが,

FIR LMRの場合と比べると低い回転準位を観 測することが原理的に可能である点が優ってい る。

L M Rは，(1) 非常に感度が高い，(2) レー ザーを掃引させる必要がない，(3) 用いたレー ザー線の周波数が精密に測定されていて個々の 研究者は周波数や波長測定をする必要がない等 の優れた点を多く備えている。実際に未だ多く の研究室で活発に用いられている。しかし一方 において波長可変の赤外光源を製作する試みが 続けられてきており, 現にそのうちのいくつか はすでに実用に供され不安定分子の分光研究に も用いられている。

このうち半導体レーザーはその代表的なもの で, $\mathrm{Pb}$ ふくむ 3 成分系の $\mathrm{p}$ 型, $\mathrm{n}$ 型一対の半 導体素子を接合させたもので， $3 \sim 30 \mu \mathrm{m}$ の赤 外領域にわたって入手することができる。組成 によって発振域が異なり，1個の素子で約 100 $\mathrm{cm}^{-1}$ 発振する。しかし素子の大きさは数分の 1 $\mathrm{mm}$ で, モード間隔が広く, 実際は上記波長域の 1/3〜1/4程度を力バーするに過ぎない。従って 広い波長範囲を連続的に掃引するには多数のレ ーザーが必要である。発振のしきい値が高いの で, 通常は15〜 $70 \mathrm{~K}$ に冷却する。温度を変化さ せても掃引できるが, 素子に流す電流を変えて 発振周波数を変化させるのが便利である。変調 感度は素子によってかなり異なるが, $10 \mathrm{MHz} /$ $\mathrm{mK}, 0.2 \mathrm{MHz} / \mu \mathrm{A}$ 程度で, 冷凍機や電源には $\mathrm{mK}, \mu \mathrm{A}$ の安定度が必要である。レーザー出力 光は偏光しているが偏光方向が一定せず, また しばしば多モードで発振する。通常25～50 cmの 分光器で出力光を分光して用いるが, モードを 充分分離できないことが多い。電流によって波 長を変化させて行くと, しばしば気付かない中 に他のモードに乗り移っていることがある。し かし出力 $(10 \sim 100 \mu \mathrm{W})$ がすべて数 $\mathrm{MHz}$ の中に 集中しているので, 光源としての輝度が高く,

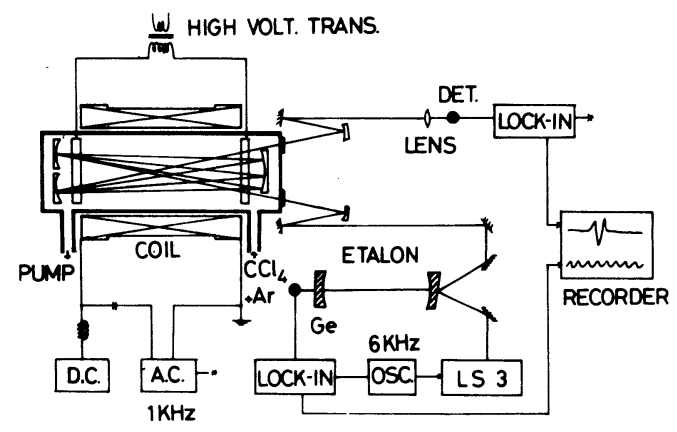

Fig. 4 Blockdiagram of a Zeeman-modulated diode laser spectrometer ${ }^{8}$.

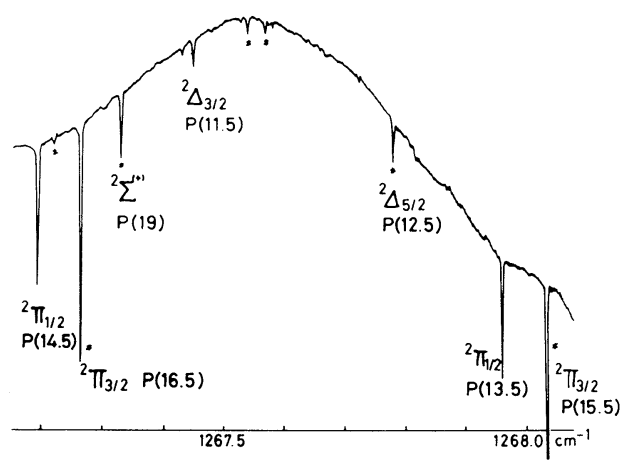

Fig. 5 A part of the ${ }^{11} \mathrm{BO}_{2} \nu_{3}$ band, recorded with video detection. Lines with an asterisk show large Zeeman effects ${ }^{9}$.

高い感度がえられる。

Fig. 4 に筆者らのグループで用いている配置 の 1 例を示す ${ }^{8)}$ 。分光器の感度を増やす為に,

Fig. 4 では光源の半導体レーザーに $6 \mathrm{kHz}$ の正 弦波をかけて周波数変調すると同時に吸収七ル (図のようにWhite 型の多重反射セルがしばし ば用いられる。物理的な長さは $50 \sim 100 \mathrm{~cm}$, 有 効光路長を10〜20 $\mathrm{m}$ にえらぶことが多い。）にゼ ーマンコイルを巻いてゼーマン変調 $(1 \mathrm{kHz})$ で きるようにしている。この他に, 通常の赤外分 光器で行なわれているように, レーザービーム をチョップして（数 $100 \mathrm{~Hz}$ ) 吸収信号を単に交 流信号に変える単純な方式もある。Fig. 5 にこ のもっとも単純な方式で記録した $\mathrm{BO}_{2}$ ラジカル $\nu_{3}$ バンドの一部を示す ${ }^{9 !}$ 。背景の曲線は光源の 素子の出力を反映している。この分子は基底電 子状態が ${ }^{2} \Pi$ なので, その 2 個のスピン副準位 


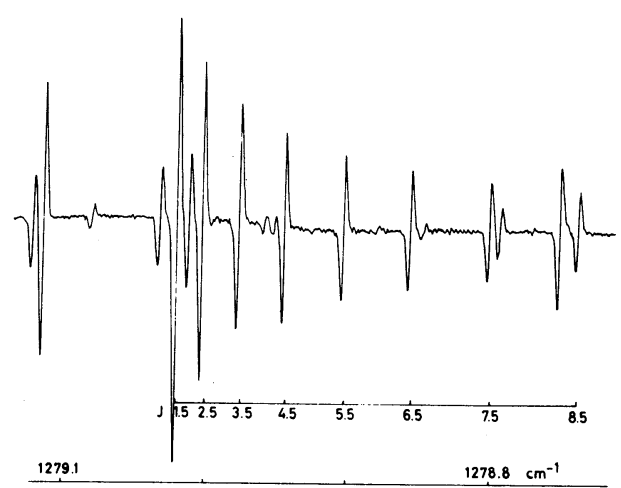

Fig. 6 A part of the ${ }^{11} \mathrm{BO}_{2} \widetilde{\mathrm{X}}^{2} \Pi_{3 / 2} \quad \nu_{3}$ band, recorded with source frequency modulation. A series of Q-branch transitions is observed ${ }^{9}$.

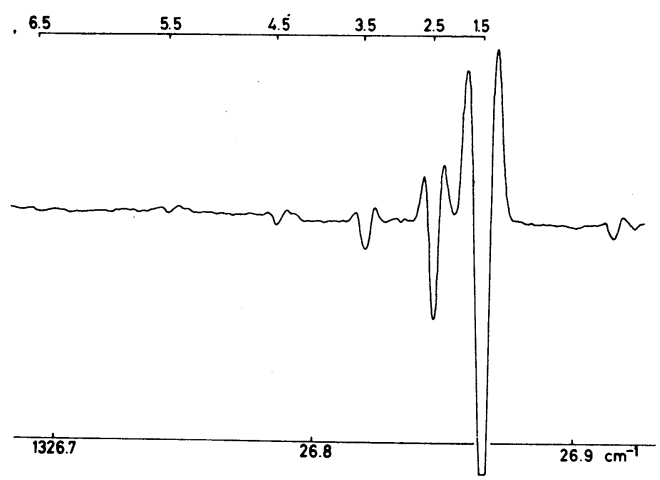

Fig.7 $\mathrm{Q}$ branch transitions of the $\nu_{3}$ band of ${ }^{10} \mathrm{BO}_{2}$ in the $\widetilde{\mathrm{X}}^{2} \Pi_{3 / 2}$ state, recorded with Zeeman modulation".

${ }^{2} \Pi_{3 \curvearrowright},{ }^{2} \Pi_{1 / 2}$ の振動回転スペクトルがもつとも 強く現われ，次いで変角振動 $\nu_{2}$ の第 1 励起状態 からのホットバンド $\nu_{2}+\nu_{3} \leftarrow \nu_{2}$ が観測されて いる。 $\nu_{2}$ 状態は振動の角運動量 $l= \pm 1$ をもつ ているので, これと電子の軌道角運動量 $\Lambda= \pm$ 1 との相互作用 (Renner-Teller効果という) およびスピン軌道相互作用によって 4 個の副準 位に分裂する。 $\left(\Delta_{5 / 2}, \Delta_{3 / 2}, \varkappa \Sigma, \mu \Sigma\right)$ 。同じ $\mathrm{BO}_{2}$ の ${ }_{3}$ バンドを光源周波数変調法で記録した のが, Fig.6である。ここでは一連の Q branch の線が現われている。Fig. 5, Fig.6のスペクトル は約 $80 \%$ 存在する ${ }^{11} \mathrm{BO}_{2}$ のものであるが，その約 $1 / 4$ しか存在しない ${ }^{10} \mathrm{BO}_{2}$ のQ branchのスペクトル をFig.7に示す。Fig.7のスペクトルはゼーマン変
調法を用いてえられたもので，これをFig.6の スペクトルと比べてみると, 約, $1 / 4$ の存在比 にもかかわらず, Fig.7のスペクトルの信号対 雑音比（ $\mathrm{S} / \mathrm{N}$ 比）はFig.6のものに比し遜色な いことがわかるであろう。Fig. 5 のチョッピン グによる方式（ビデオ検出）は当然感度が低い が, Fig. 6 の光源周波数変調方式では, レーザ 一光の反射によるファブリー・ペロー型のフリ ンジが大抵の場合 “雑音”の大部分を占める。

(Fig. 6では $J=6.5$ と $J=7.5$ の吸収線の間に顕 著なフリンジ図形がみられる。） ゼーマン変調 など分子に固有な現象を巧く使うと, フリンジ などを除去し感度を向上することができるので ある。ただし吸収線のゼーマン効果が小さいと 変調を受けにくくなり, 観測が困難となる。

Fig. 7 でJミ5.5の線が非常によわく現われてい るのはそのためである。ゼーマン変調法の欠点 の 1 つである。

波長可変レーザーは分光の目的には最適であ るが, その発振波長あるいは周波数を個々の実 験に於いて 1 回 1 回測定しなければならない。 すなわち高分解能で観測されたスペクトルに横 軸を入れなければならない。筆者ら ${ }^{10)}$ はマイケ ルソン干渉計型の波長計を製作したが，より簡 便には適当な標準試料を使うのがよい。幸い最 近分解能 $0.002 \mathrm{~cm}^{-1}$ に達するフーリ工変換赤外 分光器が市販されるようになり, 多くの基本的 分子の赤外スペクトルが $0.001 \mathrm{~cm}^{-1}$ 以上の精度 で測定されるようになってきた。このような目 的のために積極的に波数較正を目指した論文も 公表されている ${ }^{11,12)}$ 。これらの分子の吸収線を標 準とし，Fig.4に示されたようにGeレンズで 構成されたエ夕ロンを用いて補間すればよい。 Geレンズは石英管で支え, その中を真空にひい ておくと非常に安定なエ夕ロンがえられる。波 数読み取りをミニコンピューターで行なえば $10^{-4}$ $\mathrm{cm}^{-1}$ に近い再現性がえられる。

半導体レーザーは $500 \mathrm{~cm}^{-1}$ 以下（20 $\mu \mathrm{m}$ 以上）,

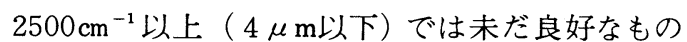
がえにくいのが現状である。このうち短波長部 については差周波レーザー, 色中心レーザー 
(カラーセンターレーザー) が開発されており， 実用に供されている。とくに後者は市販品があ り, 色中心をもつ結晶を数個用いるだけで 2 $4 \mu \mathrm{m}$ の領域をカバーすることができる。出力 は $3 \sim 30 \mathrm{~mW}$ と大きいが, 色中心を $\mathrm{Ar}^{+}, \mathrm{Kr}^{+}$ などのイオンレーザーでポンプするため, その 出力変動が赤外光の出力および周波数変動に変 換されるためかなり雑音の多いレーザー光源で ある。そこで磁場による偏光面の回転（ファラ ディ回転）を利用した偏光分光法（polaraization spectroscopy）が用いられている ${ }^{13 !}$

一方差周波レーザーは色素レーザー（連続発

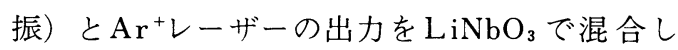
差周波の赤外光をとり出すもので, やはり 2.2 〜 $4.2 \mu \mathrm{m}$ の領域を力バーする。出力は高々 $10 \mu$ $\mathrm{W}$ と小さいが, 雑音が少ないので, 色中心レー ザーよりむしろ多くの研究室で使用されている。 半導体レーザーと比べると感度においてやや劣 るようであるが, 色素レーザーを掃引するだけ で（ $\mathrm{LiNbO}_{3}$ の温度を調整する必要あり）モ一 ドギャップなしに連続掃引できるのが有利な点 である。光源以外の他の分光系について通常半 導体レーザー分光とよく似た方法が用いられて いる。一例としてFig. 8 に筆者ら ${ }^{14)}$ が差周波分 光法によって観測した $\mathrm{HO}_{2}$ ラジカルン バンドの 1 部を示す。

最近もう 1 つ面白い差周波光源の開発が行な われている。Evenson ${ }^{15)}$ は2 台の $\mathrm{CO}_{2} レ$ ザーの出力を金属・絶縁体・金属 (metal-insulator-metal, MIMという) に照射し, 遠赤
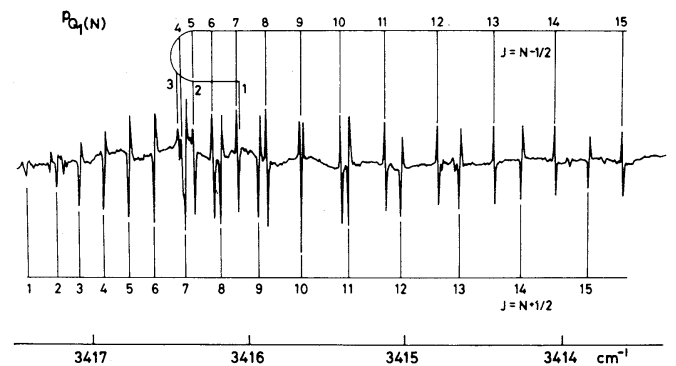

Fig. 8 A part of the $\mathrm{HO}_{2} \nu_{1}$ band observed with Zeeman modulation ${ }^{14}$.
外の差周波をとり出すのに成功した。未だ出力 は $1 \mu \mathrm{W}$ に到達していないが, より効率の高い 方法が見出されれば0.5〜3.5 THzの遠赤外領域 がカバーできるので画期的な光源となろう。

\section{3. 反応中間体の赤外レーザー分光}

2. で説明した赤外レーザー分光による研究 のうち, 主として筆者らの研究室で行なわれた ものをいくつか紹介したい。

$50064 \times 2$

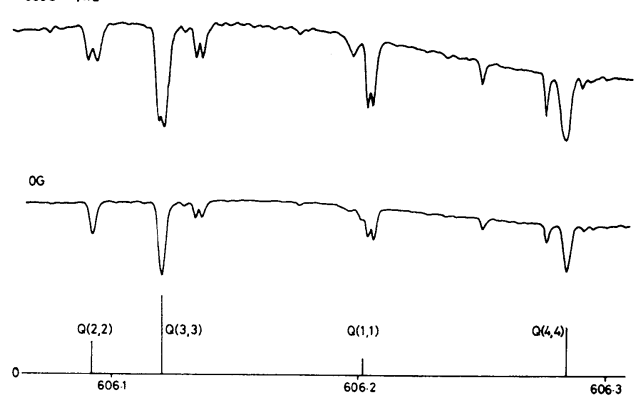

Fig.9 Q $(N, K), \quad N=K=1 \sim 4$ transitions of the $\mathrm{CH}_{3} \nu_{2}$ band, recorded with video detection. The upper trace was recorded with a magnetic field of $500 \mathrm{G}$. The radical was produced by a DC discharge in di-tert-butyl peroxide ${ }^{17}$.

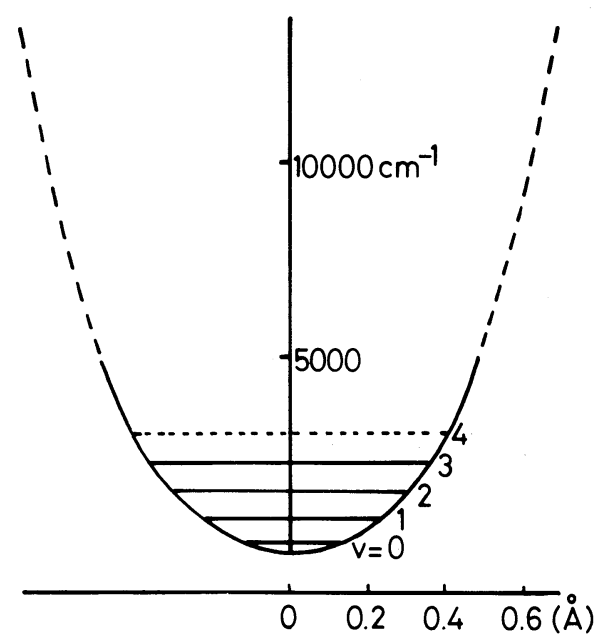

Fig.10 Potential function for the $\mathrm{CH}_{3} \nu_{2}$ mode. The abscissa corresponds to the distance between the $\mathrm{C}$ atom and the plane made by the three $\mathrm{H}$ atoms. 


\section{1 分子構造}

基本的で重要な有機化合物のフリーラジカルが がいくつかあるが, メチルラジカル $\mathrm{CH}_{3}$ はそ の代表的なものである。気相における高分解能 分光（電子スペクトル）は最初 Herzberg ${ }^{16)}$ に よって行なわれた。しかし観測された $\mathrm{CH}_{3}$ の電 子励起状態は前期解離しており, 回転構造を明 確に分離することはできなかった。僅かに $\mathrm{CD}_{3}$ の 1 個のバンドが回転構造を示し，これを手が かりとして電子基底状態では分子は平面である と推定した。筆者らは赤外半導体レーザー分光 を用いてこの分子の $\nu_{2}$ バンド（面外変角振動） を観測することに成功した ${ }^{17)}$ 。Fig. 9 にビデオ検 出によってえた Q. branch $\mathrm{Q}(N, K), N=K=$ 1 ～ 4 を示す。このようにして $v=1 \leftarrow 0$ のな らず, $v=2 \leftarrow 1,3 \leftarrow 2$ のットバンドも観測さ れ，そのバンドオリジンから Fig.10のような 面外振動によるポテンシャル関数がえられた。 一見してわかるように横軸 $r$ ( 3 個の H原子の作 る平面から $\mathrm{C}$ 原子までの距離 $)=0$, すなわち平 面構造でポテンシャルが極少值をとることがわ かる。しかしこのポテンシャル関数は大きな非 調和性 $\left(r^{4}\right.$ の項)をもっている。一方筆者らは18,19) マイクロ波分光および赤外半導体レーザー分光 によって $\mathrm{CF}_{3}$ ラジカルがかなり堅固なピラミダ ル構造をとっていることを見出した（F C F の 角度 $\left.110.76^{\circ}\right) 。 こ の 2 つ の$ 分子の中間にある $\mathrm{CH}_{2} \mathrm{~F}, \mathrm{CHF}_{2}$ の構造はどうであろうか。筆者ら は20) 前者をマイクロ波分光によって研究し, 分 子はほとんど平面であるが，完全にそうではな い徵候をいくつか見出した。

もう 1 つ筆者らが手がけたラジカルの中で興 味あるグループの分子は $\mathrm{BO}_{2}, \mathrm{CO}_{2}^{+}$である。こ れら 2 個の分子は同じ電子数をもち, ともに直 線形の構造をしており，基底電子状態は ${ }^{2} \Pi$, す なわち不対電子が 1 個あり, その軌道角運動量 $\Lambda$ は土 1 である。特に興味あるのは ${ }_{3}$, すなわ ち B-O あるい $\mathrm{C}-\mathrm{O}$ 逆対称伸縮振動である。 $\mathrm{BO}_{2}$ では $1278.3 \mathrm{~cm}^{-19 !}, \mathrm{CO}_{2}^{+}$では $1423.1 \mathrm{~cm}^{-121 !}$ と決定された。これらは関連分子 $\mathrm{CO}_{2}$ の $\nu_{3}=$ $2396 \mathrm{~cm}^{-1}$ と比べると異常に低く，それぞれの $\nu_{1}$
振動数 $1071 \mathrm{~cm}^{-1}, 1280 \mathrm{~cm}^{-1}$ に近い。さらに2 $\nu_{3}$ が $2643.5 \mathrm{~cm}^{-1}, 2938.0 \mathrm{~cm}^{-1}$ と $\nu_{3}$ 振動数の 2 倍よ り大きく, $\nu_{3}$ 振動が大きな負の非調和性をもっ ていることがわかる。筆者らはこの現象は電子 基底状態 $\left(\widetilde{\mathrm{X}}^{2} \Pi_{\mathrm{g}}\right)$ が ${ }_{3}$ 振動 $\left(\Sigma_{\mathrm{u}}\right)$ を通じて電 子励起状態 $\left(\widetilde{\mathrm{A}}^{2} \Pi_{\mathrm{u}}\right)$ と相互作用しているため ではないか（振電相互作用）と考えている。

この $\mathrm{CO}_{2}{ }^{+}$の例のように, 分子から電子を僅か 1 個取り去っただけで, しばしば分子構造に大 きな変化をひきおこす。 $\mathrm{CO}_{2}$ の $\mathrm{C}-\mathrm{O}$ 結合は $1.15979 \AA$ 无あるが, $\mathrm{CO}_{2}^{+} て ゙ は 1.1768 \AA$ になっ ている。このような分子構造論上の興味に加え て，天文学，すなわち星間空間における分子生 成過程に対する重要性から, 分子イオンの高分 解能分光研究が最近活発に行なわれている。こ れまでの結果をTable Iにまとめて示した。 検出に用いた分光法，生成法をも併記してある。 一見してわかるように，これらのうちの多くは 通常の分子にプロトン $\left(\mathrm{H}^{+}\right)$が附加して生成し たものである。対応する電気的に中性の分子は, 安定な構造（基底電子状態で）をもたないかあ るいは反応性に富んだものが多い。

以上のように分子イオンの分子構造論上の特 色は，対応する中性分子との対比において明確 であるが，1個の独立した分子としてみた場合 電荷をもっていることの効果は必ずしも明らか ではない。電荷の存在は周囲との相互作用にお いてはじめて顕在化してくるのである。例えば イオンに中性子が近ずくと, 双極子モーメント を誘起し，これと電荷との相互作用で両者の間 の衝突断面積は著しく（1２桁）大きくなる。 両者が反応する場合にはほとんど活性化エネル ギーがなく，非常に速やかに進行する。星間空 間のような低密度, 低温の環境で化学反応が進 行して種々の分子が生成するのはこのイオン分 子反応のおかげであるとされている。また電荷 はイオンを操作する（例えばイオンをビームの 状態で生成した時，イオンを加減速したりその 進行方向を変化させる）のに有用で，事実誓暳 分析法はこの事実を使って著しい発達をとげて いる。検出も電子増倍管が作られて容易になっ 
Table I. Molecular ions investigated by high-resolution infrared laser spectroscopy.

\begin{tabular}{|c|c|c|c|c|}
\hline Ion & Obs. band & Generation $^{\mathrm{a}}$ & Spectroscopic method & Ref. \\
\hline \multirow[t]{4}{*}{$\mathrm{HD}^{+}$} & $v=1-0,2-1,3-2$ & $\mathrm{HD}+\mathrm{e}$ & Doppler tuning & 1 \\
\hline & $v=18-16$ & " & $"$ & 2 \\
\hline & $v=17-14$ & $"$ & $"$ & 3 \\
\hline & $v=20-17$ & $"$ & $"$ & 4 \\
\hline \multirow[t]{3}{*}{$\mathrm{HeH}^{+}$} & $v=1-0,2-1$ & $\mathrm{He}+\mathrm{H}_{2}+e$ & $"$ & 5 \\
\hline & $v=7-5,6-5$ & " & $"$ & 6 \\
\hline & $v=1-0$ & $\left(\mathrm{He}+\mathrm{H}_{2}\right)(*)$ & difference & 7 \\
\hline $\mathrm{NeH}^{+}$ & $v=1-0$ & $\left(\mathrm{Ne}+\mathrm{H}_{2}\right)(*)$ & " & 8 \\
\hline $\mathrm{ArH}^{+}$ & $v=1-0$ & $\left.\left(\mathrm{Ar}+\mathrm{H}_{2}\right)^{*} *\right)$ & $"$ & 9 \\
\hline $\mathrm{ArH}^{+}$ & $v=6-5,7-6$ & " & Fourier & 10 \\
\hline $\mathrm{ArD}^{+}$ & $v=1-0,2-1,3-2$ & $\left(\mathrm{Ar}+\mathrm{D}_{2}\right)(*)$ & " & 10 \\
\hline $\mathrm{ArH}^{+}$ & $v=1-0.2-1,3-2,4-3,5-4$ & $\left(\mathrm{Ar}+\mathrm{H}_{2}\right)(*)$ & $"$ & 11 \\
\hline $\mathrm{KrH}^{+}$ & $v=1-0,2-1$ & $\left(\mathrm{Kr}+\mathrm{H}_{2}\right)(*)$ & $" \prime$ & 10 \\
\hline $\mathrm{CO}^{+}$ & $J=8.5-7.5$ & $(\mathrm{CO}+\mathrm{He})(*)$ & FIR side band & 12 \\
\hline $\mathrm{HF}^{+}\left({ }^{2} \Pi_{\frac{3}{2}}\right)$ & $J=2.5-1.5$ & $(\mathrm{HF}+\mathrm{He})(*)$ & FIR LMR & 13 \\
\hline $\mathrm{HCl}^{+}\left({ }^{2} \Pi_{\frac{3}{2}}\right)$ & $J=3.5-2.5$ & $(\mathrm{HCl}+\mathrm{He})(*)$ & " & 14 \\
\hline $\mathrm{HBr}^{+}\left({ }^{2} \Pi_{\frac{3}{2}}\right)$ & $J=2.5-1.5,3.5-2.5$ & $(\mathrm{HBr}+\mathrm{He})(*)$ & $"$ & 15 \\
\hline \multirow[t]{3}{*}{$\mathrm{OH}^{+}$} & $N=1-0,2-1,3-2$ & $\left(\mathrm{He}+\mathrm{H}_{2} \mathrm{O}\right)(*)$ & " & 16 \\
\hline & $v=1-0$ & $\left(\mathrm{He}+\mathrm{H}_{2}+\mathrm{O}_{2}\right)(*)$ & difference & 17 \\
\hline & $N=1-0$ & " & FIR side band & 18 \\
\hline $\mathrm{OD}^{+}$ & $N=1-0,2-1,3-2$ & $\left(\mathrm{He}+\mathrm{D}_{2} \mathrm{O}\right)(*)$ & FIR LMR & 16 \\
\hline $\mathrm{CF}^{+}$ & $v=1-0$ & $\mathrm{CF}_{4}(*)$ & diode & 19 \\
\hline \multirow[t]{7}{*}{$\mathrm{HCO}^{+}$} & $\nu_{1}$ & $\left(\mathrm{H}_{2}+\mathrm{CO}\right)(*)$ & color center & 20 \\
\hline & $"$ & " - & difference & 21 \\
\hline & $\nu_{2}$ & $"$ & diode & 22 \\
\hline & $"$ & $"$ & $"$ & 23 \\
\hline & $\nu_{3}$ & $"$ & $"$ & 24 \\
\hline & " & $"$ & " & 25 \\
\hline & $J=9-8,11-10,12-11$ & $"$ & FIR side band & 12 \\
\hline \multirow[t]{2}{*}{$\mathrm{DCO}^{+}$} & $\nu_{1}$ & $\left(\mathrm{D}_{2}+\mathrm{CO}\right)(*)$ & diode & 26 \\
\hline & $\nu_{3}$ & " & " & 27 \\
\hline \multirow[t]{5}{*}{$\mathrm{HN}_{2}^{+}$} & $\nu_{1}$ & $\left(\mathrm{H}_{2}+\mathrm{N}_{2}\right)(*)$ & color center & 28 \\
\hline & $\nu_{2}$ & " & diode & 29 \\
\hline & $\nu_{3}$ & $\left(\mathrm{H}_{2}+\mathrm{N}_{2}\right)(*)$ & " & 27 \\
\hline & $J=11-10$ & " & FIR side band & 12 \\
\hline & $\nu_{1}+\nu_{2}-\nu_{3}$ & , & color center & 30 \\
\hline \multirow[t]{4}{*}{$\mathrm{DN}_{2}^{+}$} & $\nu_{1}$ & $\left(D_{2}+N_{2}\right)(*)$ & " & 31 \\
\hline & $\nu_{1}+\nu_{2}-\nu_{2}$ & $"$ & " & 31 \\
\hline & $\nu_{2}$ & " & diode & 32 \\
\hline & $\nu_{3}$ & $\left(D_{2}+N_{2}\right)(*)$ & " & 27 \\
\hline \multirow[t]{2}{*}{$\mathrm{HCS}^{+}$} & $\nu_{1}$ & $\left(\mathrm{CO}+\mathrm{H}_{2} \mathrm{~S}+\mathrm{He}\right)(*)$ & color center & 33 \\
\hline & $\nu_{2}$ & " & diode & 34 \\
\hline $\mathrm{H}_{2} \mathrm{~F}^{+}$ & $\nu_{3}$ & $\left(\mathrm{H}_{2}+\mathrm{HF}\right)(*)$ & color center & 35 \\
\hline $\mathrm{CO}_{2}^{+}$ & $\nu_{3}$ & $\left(\mathrm{He}+\mathrm{CO}_{2}\right)(*)$ & diode & 36 \\
\hline \multirow[t]{4}{*}{$\mathrm{HCNH}^{+}$} & $\nu_{1}$ & $\left(\mathrm{H}_{2}+\mathrm{HCN}\right)(*)$ & difference & 37 \\
\hline & $\nu_{2}$ & " & " & 37,38 \\
\hline & $\nu_{1}+\nu_{4}-\nu_{4}$ & $"$ & $"$ & 39 \\
\hline & $\nu_{1}+\nu_{s}-\nu_{5}$ & $"$ & $"$ & 39 \\
\hline $\mathrm{H}^{13} \mathrm{CNH}^{+}$ & $\nu_{1}$ & " & $"$ & 39 \\
\hline $\mathrm{DCNH}^{+}$ & $\nu_{1}$ & $\left(\mathrm{H}_{2}+\mathrm{DCN}\right)(*)$ & $"$ & 40 \\
\hline $\mathrm{HCND}^{+}$ & $\nu_{2}$ & $\left(\mathrm{D}_{2}+\mathrm{HCN}\right)(*)$ & $"$ & 39 \\
\hline $\mathrm{HOCO}^{+}$ & $\nu_{1}$ & $\left(\mathrm{H}_{2}+\mathrm{CO}_{2}\right)(*)$ & $"$ & 41 \\
\hline
\end{tabular}


Table I. (continued).

\begin{tabular}{|c|c|c|c|c|}
\hline Ion & Obs. band & Generation $^{\mathrm{a}}$ & Spectroscopic method & Ref. \\
\hline $\mathrm{N}_{2} \mathrm{OH}^{+}$ & $\nu_{1}$ & $\left(\mathrm{H}_{2}+\mathrm{N}_{2} \mathrm{O}\right)(*)$ & $"$ & 42 \\
\hline \multirow{2}{*}{$\mathrm{H}_{2} \mathrm{O}^{+}$} & rotational & $\left(\mathrm{He}+\mathrm{H}_{2} \mathrm{O}\right)(*)$ & FIR LMR & 43 \\
\hline & $\nu_{3}$ & $\left(\mathrm{He}+\mathrm{H}_{2}+\mathrm{O}_{2}\right)(*)$ & difference & 17 \\
\hline \multirow[t]{2}{*}{$\mathrm{H}_{3}^{+}$} & dissociation limit & $\mathrm{H}_{2}^{+}+\mathrm{H}_{2}$ & Doppler tuning & 44,45 \\
\hline & $\nu_{2}$ & $\mathrm{H}_{2}(*)$ & difference & 46,47 \\
\hline \multirow[t]{3}{*}{$\mathrm{H}_{2} \mathrm{D}^{+}$} & $\nu_{1}$ & $\left(\mathrm{H}_{2}+\mathrm{D}_{2}\right)(*)$ & " & 48 \\
\hline & $\nu_{2}, \nu_{3}$ & " & diode & 49 \\
\hline & $?$ & $\mathrm{H}_{2}+\mathrm{D}_{2}+\mathrm{e}$ & Doppler tuning & 50 \\
\hline \multirow[t]{2}{*}{$\mathrm{HD}_{2}^{+}$} & $\nu_{1}$ & $\left(\mathrm{H}_{2}+\mathrm{D}_{2}\right)(*)$ & difference & 51 \\
\hline & $\nu_{2}, \nu_{3}$ & $"$ & diode & 49 \\
\hline $\mathrm{D}_{3}^{+}$ & $\nu_{2}$ & $\mathrm{D}_{2}+\mathrm{e}$ & Doppler tuning & 52 \\
\hline $\mathrm{CH}_{3}^{+}$ & $\nu_{3}$ & & difference & 53 \\
\hline \multirow[t]{6}{*}{$\mathrm{H}_{3} \mathrm{O}^{+}$} & $\nu_{2}\left(1^{-}-0^{+}\right)$ & $\left(\mathrm{H}_{2}+\mathrm{H}_{2} \mathrm{O}\right)(*)$ & diode & 54 \\
\hline & $\nu_{2}\left(1^{-}-0^{+}\right)$ & $\left(\mathrm{H}_{2}+\mathrm{O}_{2}\right)(*)$ & $"$ & 55 \\
\hline & $\nu_{2}\left(1^{-}-1^{+}\right)$ & " & $"$ & 56 \\
\hline & $\nu_{2}\left(1^{-}-0^{+}, 1^{+}-0^{-}\right)$ & $\left(\mathrm{H}_{2}+\mathrm{H}_{2} \mathrm{O}\right)$ or $\left(\mathrm{H}_{2}+\mathrm{O}_{2}\right)(*)$ & $"$ & 57 \\
\hline & $\nu_{2}\left(1^{-}-0^{+}, 1^{+}-0^{-}\right)$ & $\left(\mathrm{H}_{2}+\mathrm{O}_{2}\right)(*)$ & " & 58 \\
\hline & $\nu_{3}$ & " & color center & 59,60 \\
\hline \multirow[t]{2}{*}{$\mathrm{NH}_{4}^{+}$} & $\nu_{3}$ & $\left(\mathrm{H}_{2}+\mathrm{NH}_{3}\right)(*)$ & difference & 61 \\
\hline & $\nu_{3}$ & " & color center & 62,63 \\
\hline
\end{tabular}

a. (*) denotes discharge.

1. W. H. Wing, G. A. Ruff, W. E. Lamb, Jr. and J. J. Spezeski: Phys. Rev. Lett. 36 (1976) 1488.

2. A. Carrington, J. Buttenshaw and P. G. Roberts: Mol. Phys. 38 (1979) 1711; A. Carrington and J. Buttenshaw : Mol. Phys. 44 (1981) 267 ; A. Carrington, J. Buttenshaw and R. A. Kennedy: J. Mol. Struct. 80 (1982) 47.

3. A. Carrington, J. Buttenshaw and R. A. Kennedy: Mol. Phys. 48 (1983) 775.

4. A. Carrington and R. A. Kennedy: 40th Symposium on Molecular Spectroscopy, Columbus, Ohio, June, 1985.

5. D. E. Tolliver, G. A. Kyrala and W. H. Wing: Phys. Rev. Lett. 43 (1979) 1719.

6. A. Carrington, J. Buttenshaw, R. A. Kennedy and T. P. Softley: Mol. Phys. 44 (1981) 1233.

7. P. Bernath and T. Amano: Phys. Rev. Lett. 48 (1982) 20.

8. M. Wong, P. Bernath and T. Amano: J. Chem. Phys. 77 (1982) 693.

9. N. N. Hease, F.-S. Pan and T. Oka: Phys. Rev. Lett. 50 (1983) 1575.

10. J. W. C. Johns: J. Mol. Spectrosc. 106 (1984) 124.

11. J. W. Brault and S. P. Davis: Phys. Scripta 25 (1982) 268.

12. F. C. Van den Heuvel and A. Dymanus: Chem. Phys. Lett. 92 (1982) 219.

13. D. C. Hovde, E. Schäfer, S. E. Strahan, C. A. Ferrari, D. Ray, K. G. Lubic and R. J. Saykally: Mol. Phys. 52 (1984) 245.

14. D. Ray, K. G. Lubic and R. J. Saykally: Mol. Phys. 46 (1982) 217.

15. R. J. Saykally and K. M. Evenson: Phys. Rev. Lett. 43 (1979) 515.

16. M. Gruebele, R. P. Müller and R. J. Saykally: 40th Columbus Symposium on Molecular Spectroscopy, Columbus, Ohio, June, 1985.

17. M. W. Crofton, R. S. Altman, M.-F. Jagod, B. D. Rehfuss and T. Oka: 40th Columbus Symposium on Molecular Spectroscopy, Columbus, Ohio, June, 1985.

18. J. P. Bekooy, P. Verhoeve, W. L. Meerts and A. Dymanus: J. Chem. Phys. 82 (1985) 3868.

19. K. Kawaguchi and E. Hirota: J. Chem. Phys. 83 (1985) 1437.

20. C. S. Gudeman, M. H. Begemann, J. Pfaff and R. J. Saykally: Phys. Rev. Lett. 50 (1983) 727.

21. T. Amano: J. Chem. Phys. 79 (1983) 3595.

22. P. B. Davies and W. J. Rothwell: J. Chem. Phys. 81 (1984) 5239.

23. K. Kawaguchi, C. Yamada, S. Saito and E. Hirota: J. Chem. Phys. 82 (1985) 1750.

24. S. C. Foster, A. R. W. McKellar and T. J. Sears: J. Chem. Phys. 81 (1984) 578.

25. P. B. Davies, P. A. Hamilton and W. J. Rothwell: J. Chem. Phys. 81 (1984) 1598.

26. A. R. W. McKellar, K. Kawaguchi and E. Hirota: to be published. 
27. S. C. Foster and A. R. W. McKellar: J. Chem. Phys. 81 (1984) 3424.

28. C. S. Gudeman, M. H. Begemann, J. Pfaff and R. J. Saykally: J. Chem. Phys. 78 (1983) 5837.

29. T. J. Sears : J. Opt. Soc. Amer. B 2 (1985) 786.

30. J. C. Owrutsky, C. S. Gudemann, C. C. Martner, N. H. Rosenbaum, L. M. Tack and R. J. Saykally : 40th Columbus Symposium on Molecular Spectroscopy, Columbus, Ohio, June, 1985.

31. D. J. Nesbitt, H. Petek, C. S. Gudeman, C. B. Moore and R. J. Saykally: J. Chem. Phys. 81 (1984) 5281.

32 T. J. Sears: to be published.

33. N. H. Rosenbaum, J. C. Owrutsky, L. M. Tack and R. J. Saykally: 40th Columbus Symposium on Molecular Spectroscopy, Columbus, Ohio, June, 1985.

34. P. B. Davies and W. J. Rothwell: J. Chem. Phys. 83 (1985) 1496.

35. E. Schäfer and R. J. Saykally: J. Chem. Phys. 80 (1984) 2973.

36. K. Kawaguchi, C. Yamada and E. Hirota: J. Chem. Phys. 82 (1985) 1174.

37. R. S. Altmann, M. W. Crofton and T. Oka: J. Chem. Phys. 81 (1984) 4255.

38. R. S. Altman, M. W. Crofton and T. Oka: J. Chem. Phys. 80 (1984) 3911.

39. T. Amano and K. Tanaka: 40th Columbus Symposium on Molecular Spectroscopy, Columbus, Ohio, June, 1985.

40. T. Amano: J. Chem. Phys. 81 (1984) 3350.

41. T. Amano and K. Tanaka: J. Chem. Phys. 82 (1985) 1045.

42. T. Amano: 40th Columbus Symposium on Molecular Spectroscopy, Columbus, Ohio, June, 1985.

43. S. E. Strahan, R. P. Müller and R. J. Saykally : 40th Columbus Symposium on Molecular Spectroscopy, Columbus, Ohio, June, 1985.

44. A. Carrington, J. Buttenshaw and R. Kennedy: Mol. Phys. 45 (1982) 753.

45. A. Carrington and R. A. Kennedy: J. Chem. Phys. 81 (1984) 91.

46. T. Oka: Phys. Rev. Lett. 45 (1980) 531.

47. J. K. G. Watson, S. C. Foster, A. R. W. McKellar, P. Bernath, T. Amano, F. S. Pan, M. W. Crofton, R. S. Altman and T. Oka: Can. J. Phys. 62 (1984) 1875.

48. T. Amano and J. K. G. Watson: J. Chem. Phys. 81 (1984) 2869.

49. S. C. Foster, A. R. W. McKellar and J. K. G. Watson : 40th Columbus Symposium on Molecular Spectroscopy, Columbus, Ohio, June, 1985.

50. J.-T. Shy, J. W. Farley and W. H. Wing: Phys. Rev. A 24 (1981) 1146.

51. K. G. Lubic and T. Amano: Can. J. Phys. 62 (1984) 1886.

52. J.-T. Shy, J. W. Farley W. E. Lamb, Jr. and W. H. Wing: Phys. Rev. Lett. 45 (1980) 535.

53. M. W. Crofton and T. Oka: 40th Columbus Symposium on Molecular Spectroscopy, Columbus, Ohio. June, 1985.

54. N. N. Hease and T. Oka: J. Chem. Phys. 80 (1984) 572.

55. B. Lemoine and J. L. Destombes: Chem. Phys. Lett. 111 (1984) 284.

56. D.-J. Liu and T. Oka: Phys. Rev. Lett. 54 (1985) 1787.

57. D.-J. Liu, N. N. Haese and T. Oka: J. Chem. Phys. 82 (1985) 5368.

58. P. B. Davies, P. A. Hamilton and S. A. Johnson: J. Opt. Soc. Amer. B 2 (1985) 794.

59. M. H. Begemann, C. S. Gudeman, J. Pfaff and R. J. Saykally: Phys. Rev. Lett. 51 (1983) 554.

60. M. H. Begemann and R. J. Saykally: J. Chem. Phys. 82 (1985) 3570.

61. M. W. Crofton and T. Oka: J. Chem. Phys. 79 (1983) 3157.

62. E. Schäfer, M. H. Begemann, C. S. Gudeman and R. J. Saykally: J. Chem. Phys. 79 (1983) 3159.

63. E. Schäfer, R. J. Saykally and A. G. Robiette : J. Chem. Phys. 80 (1984) 3969.

た。このようなビームあるいは質量分析の手法 とレーザーを巧みに結合した分光法が展開され ている。Table Iに引用されているCarrington ら,Wing らの仕事はその代表的なものである ${ }^{22 !}$ イオンの分子構造定数のうち 1 個測定困難で未 だ報告のないものがある。双極子モーメントで ある。これを測定する1つの方法は吸収の飽和 を使うものであろう。電磁場の䡈正は，すでに 双極子モーメントの測られている中性分子のス
ペクトルによって行なえばよいであろう。

\section{2 化学反応への応用}

前述したように，筆者ら ${ }^{6)}$ は遠赤外 L M R に

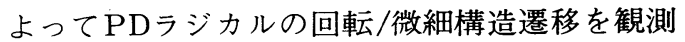
した。P Dは重水素原子と赤りんとの反応によ って生成した。重水素原子は重水素の放電によ つて容易にえることができるが，重水の放電か らも生成させることが可能である。後者を用い 
たところ P Dのスペクトルの他に吸収線を観測 した。これらの信号は， $\mathrm{D}_{2} / \mathrm{O}_{2}$ の混合物の放電 でも現われ，さらに $\mathrm{H}_{2} \mathrm{O}$ や $\mathrm{H}_{2} / \mathrm{O}_{2}$ 混合物におき あえても観測された。P $\mathrm{P}$ は従来多くのマイク 口波分光学者が検出を試みて不成功に終わって いたものである。これらの人たちの大部分はり んと酸素（原子）の反応を用いていたのである。 この事実と我々の結果を比較検討すると，赤り んは酸素原子とは直接反応せず，P H あるいは $\mathrm{PH}_{2}$ となった後に酸化されて $\mathrm{PO}, \mathrm{PO}_{2}$ あるい はHPOになると考えられる。事実反応系の中 に水があると $\mathrm{PH}_{2}$ の生成が妨げられることが確 かめられている ${ }^{23)}$ 。この例のように反応中間体 の高分解能スペクトルの観測によって, 反応機 構に関し，定性的ではあるが重要な情報のえら れた例は枚挙に暇ゔない程である。

反応中間体の赤外スペクトルを反応機構解析 に用いるには一つの大きな困難がある。観測さ れたスペクトル強度から反応中間体の濃度を算 出するには遷移モーメントを知る必要があるが， 振動スペクトルの場合その決定は一般に困難で ある。化学滴定，すなわちすでに定量的に進行 することがわかっている反応を用いて強度を較 正するなどの方法が必要である。しかし一般に はそのような情報はえられない。遠赤外 L M R で観測される純回転スペクトルの場合は，双極 子モーメントがシュタルク効果から決定できる ので直ちに反応追跡に利用できる。事実大気の 化学で重要な役割を果たしているいくつかの気 相反応速度係数が遠赤外 L M R によって測定さ れている24!

筆者 ${ }^{25)}$ は，最近光化学解離過程を動力学 的に追跡する試みを行なっている。すなわち工 キシマーレーザーによって生成した解離生成物 (反応中間体) の赤外スペクトルを半導体レー ザー分光によって時間分解して観測するのであ る。この方法は（1）放電などでは生成しにく い反応中間体が高い効率でえられる，(2) 解離 生成物の振動回転状態における初期分布から光 解離の初期過程について詳しい情報がえられる， （3）解離生成物の振動回転緩和過程，あるいは
2 次反応についても情報がえられるなど従来の 方法にはない特色をもっている。 $\mathrm{SO}+\mathrm{h} \nu(193$ $\mathrm{nm}) \rightarrow \mathrm{SO}\left(\mathrm{X}^{3} \Sigma^{-}\right)+\mathrm{O}\left({ }^{3} \mathrm{P}\right)$ の反応では, 生成 した $\mathrm{SO} v=2 に$ 約 $70 \%, v=1 に 20 \%, v=5$ に数\%存在していること, $v=1$ と 2 の状態では 回転準位の間の分布が常温のボルッマン分布か ら著しく高い状態へずれていること，同じくv $=1$ と 2 では電子スピンが分子軸に垂直な方向 に選択的に分極していることなどが見出された。 $\mathrm{CS}+\mathrm{h} \nu(193 \mathrm{~nm}) \rightarrow(1) \mathrm{CS}\left(\mathrm{X}^{1} \Sigma^{+}\right)+\mathrm{S}\left({ }^{3} \mathrm{P}\right)$, (2) CS $\left(\mathrm{X}^{1} \Sigma^{+}\right)+\mathrm{S}\left({ }^{1} \mathrm{D}\right)$ の反応では, 時間分解 質量分析 $(\mathrm{TOF})$ やレーザー誘起ケイ光 (LIF) を用いた従来の報告 ${ }^{26)}$ がCSの分布が $v=3$ に 極大をもつと結論していたが，上記の方法では C S の振動回転スペクトルがすべて吸収として 観測され $v$ の低い状態により多くの C S が生成

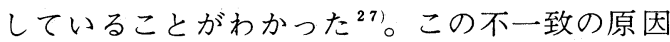
の一つは, 従来の測定では回転構造が分離され ていないため, 回転自由度へのエネルギ一配分 を実際より非常に小さく評価していたためと思 われる。最近CSの吸収線の波形をより詳しく 時間分解観測したところ, 並進運動エネルギー 分布，さらには(1)と(2)の 2 つの分解過程の寄与 の比 (branching ratio) も推定できることが わかった。

\section{3 天文学への応用}

昔から分光学は天文学と深いかかわりをもっ ており，1930年代には星の光を分光することに より $\mathrm{CH}, \mathrm{CN}, \mathrm{CH}^{+}$などの存在が同定された。 1960 年代に入り電波望遠鏡が活躍を開始し，星 間空間における分子のマイクロ波スペクトルが観 測されるようになった。こうして同定された分 子は50種を超えている。一方赤外領域の観測は はるかに遅れており，研究が行なわれたのはこ こ数年に過ぎない。地球外大気分子による吸収 のため地上からの観測に使える波長域は限られ ている。しかし風船や飛行機に上る観測も次第 に実用化されるようになってきており，赤外天 文学の将来が期待される。

赤外領域の観測によりはじめて検出可能にな 
る原子や分子がある。多くの原子はマイクロ波 領域にスペクトルを与えることは稀で，遠赤外 から赤外ないし可視・紫外部に吸収あるいは放 出線を与える。このうち特に天文学的に重要な のは Cで, その基底状態の微細構造間の遷移が 遠赤外 L M Rによって測定された ${ }^{28)}$ 。また $\mathrm{Ne}$ どの希ガスはイオンのスペクトルが赤外域に現 われる。 $\mathrm{Ne}^{+}$の基底状態の微細構造間の遷移が 事実赤外望遠鏡で観測されたが，対応する静止 周波数は筆者らの実験室でごく最近測定された。 実験室でえられる静止周波数はドップラー効果 を算出するのに必要不可欠である。

対称性の高い無極性分子も双極子モーメント が無いため回転スペクトルを与えず，電波望遠 鏡では観測されない。これらの多くは重要な分 子種である。すでにアセチレン，エチレン，エ タン, シランなどが検出されている。不安定分 子の中では $\mathrm{H}_{3}+$ と $\mathrm{CH}_{3}$ がもつとも興味ある分子 種である。 $\mathrm{H}_{3}{ }^{+}$は星間空間におけるイオン分子 反応過程で主役を演ずるイオンで，その検出は 非常に重要である。しかし赤外活性振動は2521 $.31 \mathrm{~cm}^{-1}$ で, このバンドが放出スペクトルとし て現われるためにはかなりの高温を必要とする。 すでに観測が試みられているが未だ検出されて いない。 $\mathrm{CH}_{3}$ は $\nu_{2}, \nu_{3}$ と 2 個のバンドが実験室 で測定されている。このうちでは $3 \mu \mathrm{m}(3160.82$ $\left.\mathrm{cm}^{-1}\right)$ に現われるレ ${ }_{3}$ が観測に適しているが，や はり未だ検出に成功していない。

\section{4 大気の化学への応用}

星間空間よりずっと身近な地球上層大気にも 多くの種類の分子が存在している。これらが人 間の生存条件に重要なかかわりあいをもつこと が大気污染の問題に関連して注目をあつめるよ うになり，近年これらの分子の検出に多くの努 力が払われている。例えば可視，紫外レーザー を風船に積載してLIF（レーザー誘起ケイ光） によって分子を検出することが試みられている。 吸収分光法でも，風船から数 $\mathrm{km}$ に及゙ワイヤー を垂らし，その先端に自動制御された鏡をとり つけるといった工夫により高感度検出が行なわ
れている。未だ本稿でとりあげたような反応中 間体を検出するには至っていないが, 上層大気 の论学を真に理解するにはこれらの分子種をリ アルタイムで観測することは必要不可欠で, こ の点は実験室での化学反応研究と同様である。

大気污染に関して追究の対象になっているの は $\mathrm{NO}_{\mathrm{x}}, \mathrm{SO}_{\mathrm{x}}$ と呼ばれる一群の分子である。こ の $x$ は $0.5 \sim 3$ の值をとる。代表的な分子は $x=$ $=2$ の $\mathrm{NO}_{2}, \mathrm{SO}_{2}$ であるが, その他の分子も大 部分はかなりよくしらべられている。例外は $\mathrm{NO}_{\mathrm{x}}$ のうち $x=2.5$ すなわち $\mathrm{N}_{2} \mathrm{O}_{5}$ と $x=3$ すなわ ち $\mathrm{NO}_{3}$ である。この 2 つは何れも大気中の $\mathrm{NO}_{\mathbf{x}}$ が最終的に硝酸となって洗い流され地表に戻る 過程の間に現われると仮定されている。筆者ら は $\mathrm{NO}_{3}$ をりあげ分光学的に研究を行なった。

この分子はかなり以前より $\mathrm{NO}_{2}+\mathrm{O}_{3}$ の反応で 生成すること，可視部に吸収をもつことが知ら れていたが, 分子構造の詳細は明らかにされて いなかった。最近石渡ら ${ }^{30)}$, Nelson $5^{31)}$ は400 〜680 nmにわたる吸収帯をレーザー誘起ケイ光, 励起スペクトルの観測により研究し, いくつか の振動バンドを帰属した。しかし回転構造は全 く分離されていない。最近Howard $5^{32}$ は $\mathrm{NO}_{3}$ の分子線を発生し，上記バンドの回転構造を観 測することに成功した。しかしその構造は，有 効回転温度がきわめて低いと推定されるにもか かわらず非常に複雑で，電子状態は上下ともに 単一ではないことが予想される。

筆者 $5^{33}$ は $\mathrm{NO}_{3}$ 基底電子状態の $\nu_{3}(\mathrm{~N}-\mathrm{O}$ 縮重 伸縮振動）バンドを赤外半導体レーザー分光に よって観測した。Fig.11は帰属の最初の手がか りとなった ${ }^{\mathrm{r}} \mathrm{Q}_{0}(N)$ シリーズの吸収線を示す (真中のトレース)。このシリーズは $N$ が奇数の 線のみから成立っていること, 各線はスピン回 転相互作用によって 2 本ずつに分裂しているこ とが示されている。これから直ちにこの分子は 二重項にあり, 平面構造（ $\mathrm{D}_{3 \mathrm{~h}}$ 対称性）をもつ ていることがわかる。えられた回転定数から $\mathrm{N}$ -O距離は $1.240 \AA$ と計算された。 ${ }_{3}$ バンドはこ のようにきれいに解析されたが，えられた分子 定数には異常な点が多々見られ，また解析され 


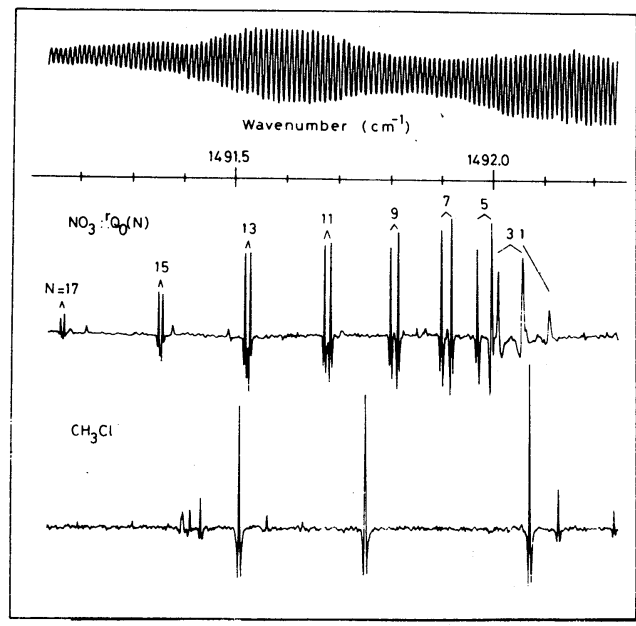

Fig. 11 A part of the $\mathrm{NO}_{3} \nu_{3}$ band observed by infrared diode laser spectroscopy with Zeeman modulation; the ${ }^{\mathrm{r}} \mathrm{Q}_{0}$ branch transitions with $N=2 n+1$ ( $n$ $=0-8$ ) are observed, each being split into two by the spin-rotation interaction $^{33}$.

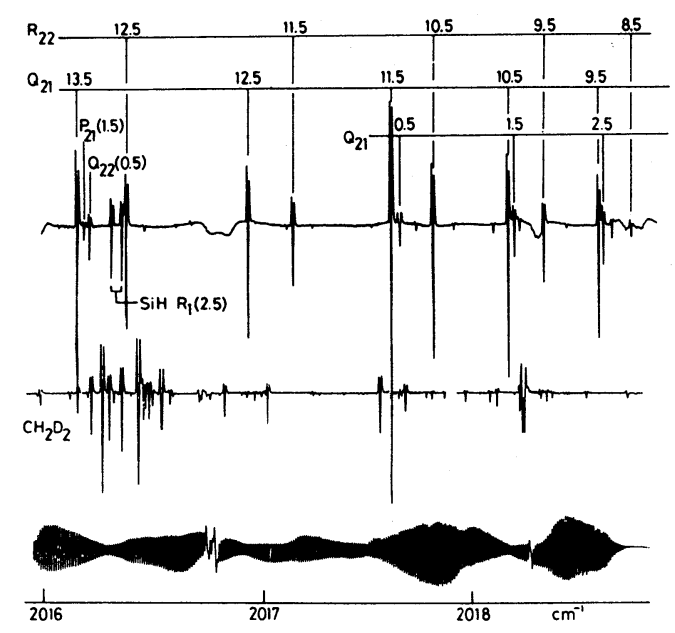

Fig. 12 A part of the $\mathrm{SiN} \mathrm{A}^{2} \Pi_{1 / 2}-\mathrm{X}^{2} \Sigma^{+} v=$ 1-0 band (upper trace) observed by infrared diode laser spectroscopy with source frequency modulation ${ }^{35}$.

たバンド以外にも帰属の明らかでない強い吸収 線が数多く観測されている。これらは基底状態 の他に低い電子励起状態が存在しているためと
推定されている。

\section{5 シラン放電プラズマの化学への応用} 最近無定形シリコンの製造に関連して半導体 工業では放電プラズマの診断に関心が奇せられ ている。このようなCVD (Chemical vapor deposition) の過程を明らかにし条件を制御す るには多くの方法が考えられようが，プラズマ 中の分子種を同定し, その量子状態分布を把握 するのも一つの有力な研究法であろう。

シラン $\mathrm{SiH}_{4}$ からシリコン $\mathrm{Si}$ が生成する放電 過程では $\mathrm{Si}_{\mathrm{n}}(n>2)$ をふくむ分子種を除外し て考えると, $\mathrm{SiH}, \mathrm{SiH}_{2}, \mathrm{SiH}_{3}$ の存在が推定 される (Table II )。このうち $\mathrm{SiH}$ は 2 原子分 子であるので, 電子, 振動, 回転スペクトルが すでに高い分解能で観測，解析されている。

$\mathrm{SiH}_{2}$ については, Duboisらが可視領域に現わ れる $\widetilde{\mathrm{A}}^{1} \mathrm{~B}_{1} \leftarrow \widetilde{\mathrm{X}^{1}} \mathrm{~A}_{1}$ を観測している。現在のとこ ろこの遷移の下の状態が基底状態で一重項と結 論されている。関連分子 $\mathrm{CH}_{2}$ はよく知られてい るように基底状態が三重項で, 最低一重項は $3165 \mathrm{~cm}^{-1}$ 高いところに存在する。これに対し $\mathrm{SiH}_{2}$ の最低三重項については全く何も知られて いない。 $\mathrm{SiH}_{3}$ についてさらに情報が少なく， 分子構造論的研究は皆無に近い。非経験的分子 軌道計算では, $\mathrm{SiH}_{3}$ はピラミダル構造をもって いて，アンモニアと同じく反転ポテンシャル障 壁が低く容易に反転するとのことである。LMR スペクトルが観測されたとの報告もあるようで あるが帰属はされていない。筆者らのグループ34) では最近赤外半導体レーザー分光によって $\mathrm{SiH}_{3}$ レ ${ }_{3}$ バンドの $\mathrm{Q}$ branch吸収線の観測に成功した。

$\mathrm{SiH}_{3}$ を研究中筆者 ${ }^{35)}$ は偶然 $\mathrm{SiN}$ の電子遷 移が赤外領域に現われることを見出した。シラ ンは空気（酸素）と激しく反応するので，筆者 らは先ずArあるいはチッ素をあらかじめ放電し ておきそこにシランを少量注入する方法をと つている。チッ素を用いた時 $5 \mu \mathrm{m}$ 領域に非常 に強いスペクトルが観測され，これを $\mathrm{A}^{2} \Pi \leftarrow$ $\mathrm{X}^{2} \Sigma+v=1 \leftarrow 0$ に帰属した。Fig. 12に観測され たスペクトルの一部を示す。このスペクトルは 
Table II. Possible reaction intermediates in silane and related plasmas.

\begin{tabular}{|c|c|c|c|}
\hline Molecule & Spectroscopic method & Obs. band & Ref. \\
\hline \multirow[t]{4}{*}{$\mathrm{SiH}$} & absorption, emission & electronic & 1 \\
\hline & Fourier & vibrátional & 2 \\
\hline & LMR & $"$ & 3 \\
\hline & LMR & rotational & 4 \\
\hline $\mathrm{SiH}_{2}$ & absorption & electronic & 5 \\
\hline $\mathrm{SiH}_{3}$ & diode & vibrational & 6 \\
\hline \multirow[t]{2}{*}{$\mathrm{SiF}$} & emission & electronic & 1,7 \\
\hline & microwave & rotational & 8 \\
\hline \multirow[t]{3}{*}{$\mathrm{SiF}_{2}$} & absorption, emission & electronic & 9 \\
\hline & Fourier & vibrational & 10 \\
\hline & microwave & rotational & 11 \\
\hline \multirow[t]{2}{*}{$\mathrm{SiF}_{3}$} & emission & electronic & 12 \\
\hline & microwave & rotational & 13 \\
\hline $\mathrm{HSiF}$ & dye laser excitation & electronic & 14 \\
\hline
\end{tabular}

1. K. P. Huber and G. Herzberg: Molecular Spectra and Molecular Sitructure, Van Nostrand, New York, 1979.

2. J. C. Knights, J. P. M. Schmitt, J. Perrin and G. Guelachvili : J. Chem. Phys. 76 (1982) 3414.

3. J. M. Brown and D. Robinson: Mol. Phys. 51 (1984) 883.

4. J. M. Brown, R. F. Curl and K. M. Evenson: J. Chem. Phys. 81 (1984) 2884.

5. I. Dubois, G. Herzberg and R. D. Verma: J. Chem. Phys. 47 (1967) 4262 ; I. Dubois: Can. J. Phys. 46 (1968) 2485 ; I. Dubois, G. Duxbury and R. N. Dixon: J. Chem. Soc. Faraday Trans. 2, 71 (1975) 799.

6. C. Yamada and E. Hirota: to be published.

7. Y. Houbrechts, I. Dubois and H. Bredohl : J. Phys. B 12 (1979) 2137; 13 (1980) 3369; 15 (1982) $603 ; 15$ (1982) 4551.

8. M. Tanimoto, S. Saito, Y. Endo and E. Hirota: J. Mol. Spectrosc. 100 (1983) 205.

9. R. N. Dixon and M. Halle: J. Mol. Spectrosc. 36 (1970) 192.

10. G. L. Galdow, C. M. Deeley, P. H. Turner and I. M. Mills: Chem. Phys. Lett. 82 (1981) 434.

11. V. M. Rao, R. F. Curl, P. L. Timms and J. L. Margrave: J. Chem. Phys. 43 (1965) 2557; V. M. Rao and R. F. Curl : J. Chem. Phys. 45 (1966) 2032; H. Shoji, T. Tanaka and E. Hirota: J. Mol. Spectrosc. 47 (1973) 268.

12. J. L.-F. Wang, C. N. Krishnan and J. L. Margrave: J. Mol. Spectrosc. 48 (1973) 346.

13. S. Saito, M. Tanimoto and E. Hirota: to be published.

14. T. Suzuki, K. Hakuta, S. Saito and E. Hirota: J. Chem. Phys. 82 (1985) 3580.

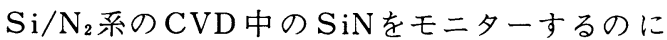
有用であろう。

Table II には関連分子として $\mathrm{SiF}_{\mathrm{n}}(n=1-$

3 ）およびHSiFを含めた。 $\mathrm{SiF}_{\mathrm{n}}$ も $\mathrm{SiF}_{4}$ の放 電でえられる。SiFについては電子スペクトル および回転スペクトルが測定されている。振動 スペクトルは直接観測されていないが，必要な 分子定数は精度よく求められており，振動回転 スペクトルを計算することも不可能ではない。 $\mathrm{SiF}_{2}$ は長寿命の分子で, すでに詳細な分光研

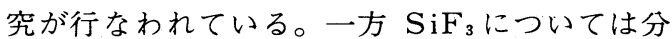
解能の低い電子スペクトルが報告されているの みである。最近斎藤と谷本 ${ }^{36)}$ は $\mathrm{Si}_{2} \mathrm{~F}_{6}$ のよわ い放電によって $\mathrm{SiF}_{3}$ を生成し, マイクロ波ス ペクトルを観測することに成功した。

$\mathrm{SiH}_{\mathrm{n}}$ と $\mathrm{SiF}_{\mathrm{n}}$ の 2つのシリーズの混合系とで もいうべき分子の中ではHSiFがもっとも基本 的な分子である。筆者らは最近 $\mathrm{SiH}_{3} \mathrm{~F}$ と Fの反 応でこの分子を生成し, 色素レーザー励起スペ クトルを観測することに成功した ${ }^{37}$ 。 
吸収分光法は感度が低く, 長い光路を必要と するため， C V Dの診断など空間的分解能が要 求される場合には必ずしも適当な方法ではない。 しかし分子種の同定, その量子状態への分布等 についてはきわめて信頼性の高いデー夕を提供 することができる。

\section{4.おわりに}

レーザーの導入により，赤外領域でも分光法 の感度が著しく向上し, 多数の短寿命分子, フ リーラジカル, 分子イオンが検出され，詳細に 研究されるようになった。本年 6 月行なわれた 第40回コロンバス分子分光学シンポジウムでも, 不安定分子, 反応中間体の高分解能研究はもっ とも重要な中心課題で，そのうちでもとくに分 子イオンに多くの関心が寄せられていた。もう 一つの課題はファンデルワールス分子の分子構 造で，これらの分子に対する赤外分光法の応用 はようやくその緒についた所といってよいであ ろう。さらにこの他の将来動向としてあげられる のは, 高分解能分光法と反応動力学の接点の模 索である。従来反応論では分光法は使用されて いても低い分解能のもので，十分な情報を提供 することができなかった。しかし本稿でも述べ たように最近では光化学反応で生成するフラグ メント分子の初期分布を高分解能分光で詳しく 知ることができるようになってきている。今後 も高分解能分光法をダイナミックな問題へ応用 する研究は活発に行なわれることと思われる。 なお本稿で論じた事項および背景あるいは関連 事項などについては最近の拙著 ${ }^{38)}$ を参照され たい。

\section{参 考 文 献}

1) G. Herzberg: Molecular Spectra and Molecular Structure III. Electronic Spectra and Electronic Structure of Polyatomic Molecules, Van Nostrand, Princeton, New Jersey, 1966.

2) K. C. Herr and G. C. Pimentel : Appl. Opt. 4 (1965) 25.

3) M. E. Jacox: J. Phys. Chem. Ref. Daata 13 (1984) 945

4) K. M. Evenson, H. P. Broida, J. S. Wells, R. J.
Mahler and M. Mizushima: Phys Rev. Lett. 21 (1968) 1038.

5) D. J. E. Knight: National Physical Laboratory Report QU-45 (1981).

6) N. Ohashi, K. Kawaguchi and E. Hirota: J. Mol. Spectrosc. 103 (1984) 337.

7) K. Kawaguchi, S. Saito and E. Hirota: J. Chem. Phys. 82 (1985) 4893.

8) C. Yamada, K. Nagai and E. Hirota: J. Mol. Spectrosc. 85 (1981) 416.

9) K. Kawaguchi, E. Hirota and C. Yamada: Mol. Phys. 44 (1981) 509.

10) K. Nagai, K. Kawaguchi, C. Yamada, K. Hayakawa, Y. Takagi and E. Hirota: J. Mol. Spectrosc. 84 (1980) 197.

11) W. B. Olson, A. G. Maki and W. J. Lafferty: J. Phys. Chem. Ref. Data 10 (1981) 1065; G. Guelachvili : Can. J. Phys. 60 (1982) $1334\left(\mathrm{~N}_{2} \mathrm{O}\right)$.

12) J. S. Wells, F. R. Petersen, and A. G. Maki : Appl. Opt. 18 (1979) 3567 ; J. S. Wells, F. R. Petersen, A. G. Maki and D. J. Sukle: Appl. Opt. 20 (1981) 1676, 2874 (OCS)

13) G. Litfin, C. R. Pollock, R. F. Curl, Jr. and F. K. Tittel: J. Chem. Phys. 72 (1980) 6602.

14) C. Yamada, Y.Endo and E. Hirota: J. Chem. Phys. 78 (1983) 4379.

15) K. M. Evenson: 16th Int. Symp. on Free Radicals, Brussels, September, 1983.

16) G. Herzberg: Proc. R. Soc. London Ser. A 262 (1961) 291.

17) C. Yamada, E. Hirota and K. Kawaguchi : J. Chem. Phys. 75 (1981) 5256.

18) Y. Endo, C. Yamada, S. Saito and E. Hirota: J. Chem. Phys. 77 (1982) 3376.

19) C. Yamada and E. Hirota: J. Chem. Phys. 78 (1983) 1703.

20) Y. Endo, C. Yamada, S. Saito and E. Hirota: J. Chem. Phys. 79 (1983) 1605.

21) K. Kawaguchi, C. Yamada and E. Hirota : J. Chem. Phys. 82 (1985) 1174.

22) Table I の文献参照

23) M. Kakimoto and E. Hirota: J. Mol. Spectrosc. 94 (1982) 173.

24) C. J. Howard and K. M. Evenson: J. Chem. Phys. 61 (1974) 1943; Geophys. Res. Lett. 4 (1977) 437; C. J. Howard : J. Chem. Phys. 71 (1979) 2352; Y.-P. Lee and C. J. Howard: J. Chem. Phys. 77 (1982) 756; J. P. Burrows, D. I. Cliff, G. W. Harris, B. A. Thrush and J. P. T. Wilkinson: Proc. Roy. Soc. London A 368 (1979) 463.

25) H. Kanamori, J. E. Butler, K. Kawaguchi, C. Yamada and E. Hirota: J. Chem. Phys. 82 (1985) 611.

26) S. C. Yang, A. Freedman, M. Kawasaki and R. Bersohn: J. Chem. Phys. 72 (1980) 4058; J. E. 
Butler, W. S. Drozdoski and J. R. McDonald : Chem. Phys. 50 (1980) 413.

27) H. Kanamori and E. Hirota: to be published.

28) R. J. Saykally and K. M. Evenson: Astrophys. J. 238(1980) L107.

29) C. Yamada, H. Kanamori and E. Hirota: J. Chem. Phys. 83 (1985) 552.

30) T. Ishiwata, I. Fujiwara, Y. Naruge, K. Obi and I. Tanaka: J. Phys. Chem. 87 (1983) 1349.

31) H. H. Nelson, L. Pasternack and J. R. McDonald : J. Chem. Phys. 79 (1983) 4279.
32) B. Howard: private communication.

33) T. Ishiwata, I. Tanaka, K. Kawaguchi and E.Hirota: J. Chem. Phys. 82 (1985) 2196.

34) C. Yamada and E. Hirota : to be published.

35) C. Yamada and E. Hirota: J. Chem. Phys. 82 (1985) 2547.

36) S. Saito, M.Tanimoto and E. Hirota: to be published.

37) T. Suzuki, K. Hakuta, S. Saito and E. Hirota: J. Chem. Phys. 82 (1985) 3580.

38) E.Hirota:High-Resolution Spectroscopy of Transient Molecules, Springer, Heidelberg, 1985. 